\title{
A Watchful Presence: Aesthetics of Well-Being in a Japanese Pilgrimage
}

Jason Danely, Oxford Brookes University

\begin{abstract}
:
This article examines practices of watching and walking as aesthetic staging grounds for the embodiment of social values, well-being, and aged subjectivities. Using a small, grassroots neighbourhood-watch "pilgrimage" created by and for older adults in Kyoto, Japan as my primary case study, I describe how the sacred meanings of pilgrimage come to inhabit spaces of civic social engagement (and vice versa) and elder subjectivity through practices of mapping, record-keeping, and ritual. I argue that following these practices with the older adult pilgrims leads us beyond what Coleman (2002) referred to as a theoretical "pilgrimage ghetto," and creates openings to engage with multiple registers of intersubjective practice: watching and being watched over; grounding and transcending. Watching and walking also contest the marginality, dependence, and precarious invisibility that dominate popular discourse on aging in contemporary Japan.
\end{abstract}

Keywords: pilgrimage, Japan, aging, community, visibility, walking 


\section{Introduction}

This article examines the creative and aesthetic production of space and subjectivity through practices of watching and walking. It is also about pilgrimage, leaving aside, for now, the question of how and where pilgrimage overlaps or articulates with other practices. Pilgrimage might be minimally defined as the process and practice of making a special journey to one or more sacred sites (Reader and Swanson 1997, 228). Many scholars have used pilgrimage to think more broadly about metaphors of identity-building (Bauman 1996), ways of practicing space (de Certeau 1984, 130), or sites of contestation, where multiple subjectivities and religious or spiritual practices can emerge (Eade and Sallnow 1991).Ethnographies of pilgrimage, in particular, move us beyond formulas based on static destinations and illustrate the complex links between emplacement and mobility, "home" and "away," (Coleman 2000) as dynamic patterns arising through what Bajc et al. (2007, 325) describe as "bifurcation" and "fractals," echoes and inspirations that find their ways into the narrative of (re)iterations of pilgrimage in different times and places.

In order to resist the urge to drift too far into loose abstractions distanced from the lived experiences of pilgrims themselves, I ground this ethnographic description first in the activities of watching and walking and the feelings and meanings produced in these practices, and second, in the potentials and regimes of value that emerge when these practices are placed within the cultural frame of the pilgrimage. It is my hope, then, that this approach will bring into greater relief the subjective and moral stakes of pilgrimage, and at the same time, create openings within the frame of pilgrimage for thick flows of meaning between the secular and the spiritual, the individual and the social.

I argue that in Japanese pilgrimage, the path and the person are linked in a process of creating watchful selves and walking bodies, a process that cannot be reduced to ideology or religious dogma, but which draws together different strands of age-related notions of social 
and spiritual well-being, and enunciates the forms of moral responsibility, agency, and power individuals and communities have as they attend to well-being. since neither pilgrimage, nor aging, nor the desire for well-being are unique to contemporary Japan, how should one tell a story about these things, and the family resemblances they share with pilgrims of other places and times?

Like most anthropologists educated over the last three decades, I was first introduced to pilgrimage through the work of Edith and Victor Turner (1978) and their notions of communitas and liminality, spiritual and social modes that gave pilgrims an experience of communality, striving on the same path. Later I would be introduced to others who embraced or expanded on the Turners' work (Desjarlais 1989; Dubsich and Winkleman, eds. 2005; Notermans 2007; Smelser 2009), each emphasizing the role of symbol, narrative and transformation brought about by the ability of the pilgrim to escape from under the structures of the mundane world. Other scholars presented pilgrimage from a Marxist perspective, such as Benedict Anderson (1991), who pointed out that pilgrimage also functioned historically to organize relationships and structures of power, expanding the outer limits of religious identities while simultaneously consolidating hegemony among otherwise unrelated people and places (1991, 53-54). Anderson showed how these movements become enfolded within other political and secular ways of imagining being (capitalism, colonialism, nationalism, e.g.), as print media displaced the pilgrimage as a technology of knowledge-power (1991, 55-58). P. Steven Sangren's (1989) analysis of the Ma Tsu Pilgrimage in Taiwan extends the Andersonian challenge to Turner by arguing that pilgrimage organizes idioms of connection to transcendent power, linking local cults to main cult centers outside of and transcendent to the community. Reading pilgrimage through the lens of "alienation" and "fetish," he argues that pilgrimage produces representations that structure desire, rather than an "anti-structure" that provides the individual with a means of 
escape $(1989,564)$.

It seems that today, things stand much as they did over a decade ago, when Simon Coleman's critical review of pilgrimage studies (2002) examined both the common ground and points of debate that have arisen within anthropology since Turner and Anderson. In his conclusion, Coleman urges scholars to "broaden our theoretical and ethnographic horizons" $(2002,363)$ and follow the overlapping areas between pilgrimage and other forms of sociality and identity, but perhaps most importantly, to be aware of the ways definitions and categories can creep into our assumptions and assertions, obstructing, rather than pushing our understanding forward.

Though the language of 'pilgrimage' (junrei) was used by the older adult participants in the case study I will describe here (indeed, it had critical symbolic significance for them), I often wondered what would be gained, analytically, by introducing the term as an etic device for this inquiry. What might be gained by instead, beginning with the ways older Japanese people engaged with their world through everyday practices of watching and walking? In bracketing pilgrimage for the moment and looking at both the micropractices and broader social discourses around watching and walking, I began to see the Japanese pilgrimage as a means of expressing social tensions, values, and commitments, and bringing about shifts in subjectivity; as pilgrims, participants were not just older people, but also moral agents, carers, good citizens.

Though I soon return to pilgrimage, I begin this article with a brief description of the significance of watching and walking in Japan. I will then introduce my primary case study, wherein discourses and practices of watching over (mimamori) and walking around (ayumu) become entangled with other social concerns centered on the aging community.(1) In order to understand this entanglement, however, I will introduce some details about the role of pilgrimage in Japanese religious understandings, and the connection between watching over 
and wandering around signified sacred images of Jizō Bodhisattva. The last sections of the article show how practices and narratives become anchored in and aestheticized by the materials and rituals of pilgrimage, and how these open up possibilities for experiencing older adult subjectivity and well-being in the context of social insecurity.

\section{Walking}

Tim Ingold (2004), following Erving Goffman (1971), has argued that walking city streets requires not only a particular kind of "visual vigilance" and social interaction, but also that technologies like leather boots and paved roads render watching and walking, scanning and ambulating as separated realms of experience $(2004,329-330)$. How one walks affects how one ought to watch, and vice versa. As a counterpoint to the modern western way of walking, Ingold looks at the Japanese, whom he sees as "strongly and positively oriented towards the ground," such that they do not make such strong divisions between humans and nature, looking and locomotion. "What new terrains might be opened up?" Ingold wonders, if, like the Japanese, we were to adopt a "fundamental orientation toward the ground" (2004,331).(2)

Ingold's open-ended question resonates with the feelings of many of the Japanese urbanites, both young and old, whom I spoke with during my fieldwork in Kyoto, and while traveling along the Shikoku Henro pilgrimage route. Many spoke about walking as having a deep, psychological and somatic relationship with the landscape and community. Waiting to watch a Noh performance (Okina) one morning, for example, a man sitting beside me told me to watch the way the dancers moved feet, placing them fully over the wooden stage rather than up on their toes. "It may sound like bragging," he said, "but it always gives me an overwhelming feeling of affinity and oneness with the natural world," from the gravel to the winds, to the crows cawing overhead. "I don't understand the meaning of anything they 
say," he continued, "but every year I see the okina, I am filled with the joy of just being alive (ikiru yorokobi)." For this man, the gravitas of the okina dancer tied together heaven and earth, restoring and renewing while linking bodies and places, pasts and futures. Neighborhood shrine processions, fire safety patrols, Buddhist alms begging, and other forms of ambulatory circulation model link the local to locomotion; walking implies an everyday ethic of neighborly greetings and exchanges that cement local attachments.

The important orientation of walking, was not between the walker's origin and their destination, but between the body and the ground beneath. Being "down to earth," feeling the surface of the ground on one's feet was seen as an embodiment of humility, something evoking a sense of nostalgia for the bodies and values of an imagined Japanese past. One man in his thirties, for instance, told me that he always "feels sad" when he sees Japanese people with "long legs" these days, sleeping on beds and sitting in chairs, as if the bodies themselves were now becoming irreparably distanced from their heritage as they were physically distanced from the ground. "Japanese people cultivate rice," he explained, "and so they were always down in the rice fields, and it was good to be low to the ground." He went on to explain that Japanese people needed longer torsos to digest the rice, and, since rice cultivation also required cooperative labor and a shared supply of clean water, being low to the earth also implied interdependence and mutuality. If one farmer were to pollute the water, he explained, farmers elsewhere would get upset, because everyone had to share. In this man's narrative, social values not only followed, sometimes reluctantly, the relationship between the body and the common ground, but the body itself was a barometer of proximity to social values. Older bodies are also sites of ethical aspiration and struggle, as increased longevity, smaller families, and alarmist welfare discourse contribute to fears of physical dependence, chronic illness, abuse, and abandonment (Danely 2014; Traphagan 2006). This is particularly true for the 'young-old' (those between 65 and 75), many of 
whom continue to work past retirement or take up leisure activities, join clubs, and attend exercise groups to prevent senility or immobility (Traphagan 2000a). Many join walking groups or take up hiking, often to famous pilgrimage sites or places with religious significance for older persons where one might pray for a quick death without disability ('pokkuri,' or 'pin pin korori') (Young and Ikeuchi 1997). The healthy body and mind express efforts to reduce burden on others, be they one's family, community, or the nation.

For older adults who are less independent, such as those I conducted research with in day-service centers, however, walking, especially when unobserved, was considered deviant, even reckless, in the view of the staff. From the time they arrived at nine in the morning, until they left at four in the afternoon, most day-service users sat in their chairs, moving only when watched or accompanied by the staff (going to the toilet or the bath). Walking was opposed not only to sitting, as it may be elsewhere (Ingold 2004, 322-323), but more directly, to tripping and falling (kokeku). Among care professionals and older adults themselves, the constant hazard of falling in old age was frequently repeated and morally weighted, since falls would easily lead to injuries that reduce one to the medical and welfare administrative category of the "bed-ridden" (netakiri) elderly (Long 2003). Becoming netakiri, like becoming senile (boke), incurs a kind of social death while at the same time burdening others with one's dependence; it is a foreclosure on self-care, and was thought to inevitably lead to further cognitive and muscular degeneration that would impede rehabilitation.

In contrast, the moral elder watches where they walk, takes strolls in and around their neighborhood, attends muscular training activities hosted by senior welfare centers, and occupies their time with awareness and efforts at preventing falls. In this sense, Watching out and walking out direct the self towards a reappraisal of the outer world that can produce changes in the inner world, less an escape from the everyday or seeking 
purpose in the "out there," than a means of its revelation as a moral and bodily practice; it is an aesthetic practice of well-being as balance (Rapport 2007, 102).

Walking a pilgrimage condensed values of physical self-reliance, mental discipline, and spiritual serenity into the everyday experience of movement through outdoor spaces. Walking meant well-being. Exchanges like the following, with 71 year old retired salaryman Ishida-san were typical:

Danely: Why did you think about doing this pilgrimage?

Ishida: Everyone goes on pilgrimages! For me I started after my wife died. I waited a while, then after a while I started. On the Saikoku Pilgrimage.(3)

Danely: How long ago was your first time?

Ishida: Well, ten years ago.

Danely: Since you retired?

Ishida: Right. Part of my thinking was that it would be walking. Walking, walking, walking (making sounds of exertion)—-something good for my health — that was one of my goals. And then being out there in the mountains and so forth. And then visiting the temples.

For Ishida-san and others I spoke with, walking was seen as a means to health, followed by being "out there" in the mountains and finally visiting temples. In the aftermath of his wife's death, walking was the experience that made self-care possible. We might even go so far as to say that it even made the perception of "being out there" as a moral self possible.

For the older adults living in a neighborhood of northwest Kyoto, Japan, where I lived and conducted research, walking and watching were key constitutive elements of one of the most successful community-building projects the local social welfare association had ever devised: a six-month "neighborhood-watch program" (mimamori kōban), which took 
the form of a wandering pilgrimage to the twenty-five community managed roadside Buddhist shrines.(4) By walking though and watching over the familiar neighborhood streets as pilgrims, this innovative program, called the "Shūni O-Jizō-san Pilgrimage,"(5) not only facilitated a local re-imagination of the moral landscape of civic and spiritual responsibility (cf. Kawano 2005; Porcu 2012; Robertson 1991), but it also created possibilities for experiencing new watchful subjectivities that diverged from pervading representations of older people as marginal, dependent and invisible (those needing to be watched over). As 'pilgrimage,' practices of watching and walking constituted a staging ground for the creative embodiment of age, and the performance of moral, spiritual, and aesthetic practices-- mapping, record-keeping, reporting, offering, chanting-flowing between regimes of value marked as sacred and profane, individual and community wellbeing. Understanding this case study requires an "unbounding" of the pilgrimage (Dubisch 1995, 46; Reader 2005, 34), stepping outside what Coleman referred to as the "pilgrimage ghetto, a theoretical cul-de-sac where it is assumed that the only relevant points of debate relate to other studies that purport to focus on pilgrimage" (2002:363).

Japanese pilgrimage is constantly exceeding its immediate context and meaning through acts of aesthetic and indexical transposability, or its wayfaring and wandering off to other meaningful paths. What makes the Shūni O-Jizō-san Pilgrimage an ideal case to view this transposability is that unlike the more well researched and popular pilgrimage routes, it was small, locally confined, and unburdened by powerful institutional organizations or long historical traditions. To say that it is without a history is not to say that it cannot or should not be analyzed in its cultural context, which most certainly includes other pilgrimages. Indeed, the organizers and participants, like Ishida-san above, frequently and selfconsciously referenced the pilgrimage tradition of the more prestigious, religiously-affiliated routes, and relied on the cultural scripts underlying these pilgrimages to make their own 
iteration culturally meaningful. However, the Shūni O-Jizō-san Pilgrimage was undoubtedly 'original' in the sense that I was able to observe the first time this specific pilgrimage had ever been organized and practiced (something rare in most accounts of pilgrimage), and consequently both I and the other participants could embark with a shared sense of pioneering.

The following sections describe the origin and organization of the Shūni O-Jizō-san Pilgrimage - its formal protocol and improvisatory open-ends - concentrating on the ways participants inhabit the living design of the pilgrimage, generate aesthetic and material representations of their community, and embody well-being in old age.(6) My ethnographic descriptions, like the cyclical, continuous route of the pilgrimage itself, however, begin in medias res, interfering with a sequential narrative of a rite de passage in favor of an ethnographic approach of repetition and circulation that brings possible pasts and futures into play with the present (Danely 2012a). My narrative of Japanese pilgrimage wanders off the path to secondary sites of interest, regains its footing, maps and re-maps what it observes, and ultimately, hopefully, brings us closer to understanding why pilgrimage works well, and works as well-being for older people in Japan.

\section{Watching}

Kawashima-san, a 75-year-old retired shopkeeper and leader (kaichō) of the Shūni School District Social Welfare Cooperative, stood in the corner of the community meeting room wearing a cream colored baseball cap with the red smiley-face insignia of the district pinned to the front. With his arms to his sides he looked out over the room through thick, angular glasses and smiled. “Good morning everyone!” Kawashima-san belted, starting the meeting. The room of forty-five older adults seated on the ground at low folding tables replied, "Good Morning!" with matching gusto. 
The main purpose of the meeting, Kawashima-san explained, was to discuss the community efforts to set up a neighborhood watch program for watching over schoolchildren (kodomo mimamori kōban). Over the year preceding this meeting, a number of sensational news reports involving children commuting on foot to school, including fatal traffic accidents and abduction, had been circulating in the media(7). While the overall rate of these incidences had not risen significantly in Kyoto during the time of these reports, the circulation of the stories, like rumors, drew on the tensions and ambiguities around walking and watching and dramatized them. Wandering and invisibility were dangerous, but walking and being watched were safe.

At the meeting, Kawashima-san, like most of the Japanese older adults I spoke with, was quick to attribute the reports of school commuting dangers to broader social problems he considered endemic in Japan's post-war generation, especially "selfish individualism" and weakening community ties, materialism and fast-paced living, and perhaps most tellingly, the epidemic of "forgetting" the hardships and the lessons of older generations, a condition he referred to disparagingly as "peacetime idiocy" (heiwa boke). Kawashima-san felt a sense of legacy and responsibility to keep the neighborhood from falling into dangerous complacency. The stakes of watching were life and death, for both young and old.

Although Kawashima-san had proposed a neighborhood-watch for schoolchildren in the past, he had little success coordinating with other local groups. Addressing the meeting, he once again reviewed his past confrontations with members of the local Parent Teacher Association (PTA), school principals, and local officials, most of whom expressed sympathy with his concerns, but variously responded that the children are not the responsibility of the community at-large, but of other institutions like the family and the school. Without the material support of these other civic groups, Kawashima's neighborhood-watch program seemed to be doomed. 
Most of the attendees listened attentively to Kawashima as he described his efforts, some nodding in earnest sympathy. After about twenty minutes, however, a few heads had already lowered and others seemed to be dozing off. Eventually, Kawashima-san changed his tone, brightening up again to deliver his report on the group's latest successful neighborhood-watch project:

So! Other things aside, the older adults have been doing the Jizō Pilgrimage for us. The participants - well, you see, this [pilgrimage] is four circuits. We have twentyfive locations and we arranged it so that you go around to them all once, twice, three times, four times in all before you complete it (mangan) — and so it's a pretty tough requirement! That said, there have already been two people who have filled their stamp books!

At his announcement, the group became instantly animated, raising eyebrows, filling the room with oohs of impressed approval, and initiating side-conversations with one another. Kawashima-san, clearly enjoying the reaction, continued his praise:

Out of these, one person told me the other day, they would sometimes go around to 15 or 16 stations in a day! (laughter from the group) I told this person, "You're making this your job!" I was pretty surprised when they told me “Hey, I don’t know why you think this is going to last people half a year-I did the whole thing in a week flat!" (more laughter from the audience)

Not only had participants completed the pilgrimage and the neighborhood-watch function it entailed, but they were doing it frequently and repeatedly, exceeding the expectations of Kawashima-san and the other group members. While only a couple of participants had made four complete rounds, an informal survey of the meeting attendees confirmed that most had made a partial pilgrimage and planned to complete at least one circuit over the coming month. The news of the pilgrimage's popularity only a month after it 
had been initiated, and the many remarks about the achievements of the group's members lasted long after Kawashima-san's announcements had ended, as several of the women members brought out small trays of sushi donated from a local restaurant and cans of beer for the meeting attendees, encouraging a festive atmosphere, even at eleven o'clock in the morning.

The enthusiasm and laughter at the meeting offered a resounding approval of the pilgrimage, which had succeeded where several other attempts at neighborhood-watch programs had failed: it was able to orchestrate and mobilize older adults into the streets of the community in a way that produced a sense of both personal achievement and social commendation and it was able to maneuver around the institutional obstacles posed by local schools, officials and families.(8) It offered a sense of community beyond the meeting room walls and beyond the tacit boundaries between generations, though not in the sense of spiritually framed communitas (Turner 1978) nor as a ‘imagined community' based on nonspiritual values, technologies, and structures (Anderson 1991). What made the pilgrimage so effective at this, and how did the pilgrims' age contribute to the meanings of the watch?

Before answering these questions, we need to first attend to the activity of "watching," and more specifically "watching over," or mimamori, and how the pilgrimage enabled this practice. Kawashima-san's remarks on the deterioration of social values and forgetting hinted that this watchfulness may be much more than simply looking out for physical dangers, and entailed a keeping watch over civic morality. Such watching creates a means of knowing the world, of seeing its value, of shifting one's position to follow its curve.

\section{O-Jizo-san and being a watchful presence}

On the formal level, the Shūni Jizō Pilgrimage was conceived by Kawashima-san 
and others in the Social Welfare Cooperative Association as fulfilling two purposes: A) it was a means of monitoring the safety of school children, B) it would be an opportunity for older adults to engage in neighborhood activities outside the home. Hence, the pilgrimage would attend to two vulnerable groups at opposite ends of the age spectrum representing two forms of emplacement and mobility: moving children and homebound elders. These groups would be linked not by any direct interaction with one another, but through the watchful supervision of the elders (who cannot peer from behind drawn curtains, but must become exposed themselves), and the parallel, simultaneous walking through the neighborhood streets.

This dual revelation of watching as both surveillance and exposure links the civic purpose to the sacred sites and objects of the pilgrimage: shrines to the Bodhisattva Jizō (Skt. Kșitigarbha). O-Jizō-san (in local vernacular) is perhaps the most popularly revered Buddhist icon in Japan today (Chozen Bays 2001; Glassman 2011; Fujiwara 2012; Porcu 2012), and is usually represented as an itinerant Buddhist monk with a smooth, round head, dressed in simple robes and carrying a staff (Figure 1). Jizō-san is not only identified with boundless mobility and omnipresence, but he is also associated with the watching over children, travelers, and sometimes older people (Danely 2012b) as well as the salvation of children and fetuses suffering in the other world (LaFleur 1992; Moerman 2005, 132). Those caring for a Jizō statue often leave offerings of children's clothes or toys, and may dress the statue with handmade bibs or hats.(9) As an object of meditative practice, statues of O-Jizō-san are both visualized and visualizing, watched and watching over.

Figure 1: A statue of the Bodhisattva Jizō (photo by author)

There are Jizō shrines throughout Kyoto, not only at Buddhist temples, but also 
located on each block unit, or $c h \bar{o}$, in recognition of his role as a sort of tutelary guardian of a locality. Each shrine is maintained by the $c h \bar{o}$ organization, a neighborhood volunteer association with no formal religious ties. This link between the shrines and the block associations was not viewed as problematic, and it did not entail further obligation towards outside religious institutions or activities.

Each block's shrine was unique, but usually consisted of a small wooden structure (hokora) set on a stone pedestal about the height of a small vending machine. The structure is meant to stand just below eye-level to a standing adult, and just above eye-level of a child. Jizō shrines are sometimes tucked beside a school gate and other times may be set next to the entrance of a liquor shop, easily blending into common city surroundings. Banners with civic morality slogans are often tacked to walls next to these shrines (Figure 2), as are plaques or monuments bearing the words "Safe Chōnai" (chōnai anzen), further evidence of their function as emblems of the $c h \bar{o}$ 's spirit of watchful responsibility. The multiplicity of images of Jizō and his seemingly sudden appearance in everyday locations reinforces the notion of his watchful presence (Danely 2012b).

Figure 2: A simple neighborhood shrine for Jizo next to two civic association banners. The banner on the right reads "Make way for each other. That's the spirit that will decrease accidents". The banner on the left reads "Closeness [lit. mutual contact] and Conversation [in the present] will make [lit. nourish] the future of the children." Banners like these are often seen close to shrines. (photo by author)

The Shūni Pilgrimage did not include stops to worship statues at temples, cemeteries and informal roadside shrines, but was limited to the officially designated $c h \bar{o}$-based shrines. In 
the Shūni school district there were twenty-five $c h \bar{o}$, and so the pilgrimage would include twenty-five stations.

One pilgrim remarked that in old age he feels a duty to watch over the children because it gives him the sense that "life and death form a natural cycle" (sei to shi ha tözen no saikuru). Just as past generations watched over him when he was young, now he was able to do the same for the children in the community. Japanese pilgrimages typically consist of several linked sacred locations (reijo) ordered as a circuit, rather than directed towards a singular goal (Reader and Swanson 1997; Statler 1983). In the Shūni O-Jizō-san Pilgrimage, Kawashima-san chose four circuits (a total of 100 stations) as constitutive of a complete pilgrimage-watch (mangan, or "wish fulfillment"), but the circuit could be made perpetually like a police officer (O-mawari-san, literally 'Mr. Going-Around').(10) However, unlike policemen on rounds, pilgrims sometimes stopped en route to chat with friends, or wander off the "path" to visit secondary sites of religious interest like temples or graves, and informal stops, like shops and cafes.

The designation of Jizō as the primary object of the pilgrimage provides both the comforting sense of being watched over and a model of watching over others. Many had fond, nostalgic memories of celebrating Jizō bon when they were young, gathering at their local shrine to pray, play, and receive sweets. While they are still celebrated, many remarked sadly that they are much smaller than in the past, with several blocks consolidating their events due to the lack of children and the lack of interest among many young families. Jizō not only condensed memories and meanings, but provided multiple material sites of observance and repetition. Like the older adults themselves, Jizō appeared everywhere but was routinely ignored, an incidental part of the landscape hidden behind the wooden lattice of the shrine structure or weathered and worn like any other chunk of stone. He is caught in the web of perpetual interdependence, but his vow to watch over those in need keeps him 
present. The pilgrimage activates these statues and the older adults that visit them as objects to be watched and as watchers themselves, making them visible to themselves and others in new ways.(11)

\section{Mapping Bodies of Social Change}

The Shūni O-Jizō-san Pilgrimage was not only meant to facilitate connections between the pilgrims and the local Jizō shrines, but also between older adults, children, and other neighbors, the assumption being that such interaction is quickly diminishing in contemporary urban Japan's “connectionless society” or “muen-shakai” (Morioka 2012; Rowe 2011; Takenaka 2000; Yabe 2012). Discourses concerning muen-shakai consolidate several social concerns that seem to have merged in the context of Japan's economic stagnation of the 1990s and early 2000s. One of the most prominent discourses was "shoshikōreika", or the "low fertility, aging society shift" (Kojima 2000; Roberts 1996). While the welfare of older adults was becoming less secure and more burdensome on society, younger generations were facing a similar insecurity as a "lost generation" (Genda 2007; Ishiguro 2008; Zielenziger 2007). The neighborhood-watch/pilgrimage was constituted from these discourses but also physically and conceptually redesigned and remixed it, and it was the elders themselves that were taking the lead.

The year the pilgrimage began (2006), those over 65 made up $22.2 \%$ of the population in the Shūni school district. In 2013, that number had risen to 27.8 percent (Kyoto City Bureau of Population Statistics 2014). When I asked how this trend was affecting the neighborhood, Kawashima showed me a brief questionnaire he wrote to assess the "needs" of adults over 70 living in Shūni, which he distributed before launching the Jizō pilgrimage. Although he did gather some information about household composition and utilization of health and care services, he was also interested in neighborhood and community 
involvement. One of the most striking results of his survey was that of the 821 respondents, 618 (75.2 percent) indicated that they felt no "relationship with the neighborhood" (Kinjo to no tsukiai). Kawashima-san, who was born and raised in Shūni, contrasted this with his childhood memories, when cooperative mutual aid associations were central to the livelihoods of the residents of Shūni, in everything from finances, to farming to funerals.

A few months after Kawashima-san showed me his survey, he was ready to introduce the pilgrimage at a festive gathering hosted by the Welfare Association in a neighborhood park. The gathering was an annual fundraising event called the "Ajisai Matsuri" (Hydrangea Festival), held at the peak of the blooming period in late June. No mention of the pilgrimage had been made in announcements for the gatherings, which also included a performance of the older persons' chorus group, food, and some light exercise. I later found out that Kawashima-san and the other officers of the Welfare Association had been planning the activity for months, while I had been conducting research in other parts of the city.

I was happy to see so many of my older neighbors and friends come out to the event that morning despite the stifling heat and humidity. Nearly all of the attendees came on foot, many keeping their balance with wheeled carts or canes, walking slowly and carefully over many of the same paths the schoolchildren took to school. There was, however, a conspicuous lack of children or families in attendance, making the park playground area seem lonelier than usual. Still, the turnout was impressive, and the mood was light.

Many of the attendees were already sitting on the park benches eating and drinking, or strolling around the hydrangeas chatting with friends. I found a group of men I knew jostling shoulders around a steaming pot as they cooked servings of noodles or potatoes. All the men wore bright white T-shirts and baseball caps emblazoned with the name and logo of the welfare association: the simple round smiley face named "Shū-chan". Soon, I was in next to them, gossiping about who did or didn't show up, or teasing the women who made up the 
majority of those in attendance.

Figure 3: Members of the Shüni Social Welfare Cooperative Association gather around a tent where volunteers distribute booklets and maps for the pilgrimage

After a while I realized that I had forgotten to check-in at the reception tent, where Kawashima and the other organizers were mulling around, selling tickets to exchange for food and drinks, and distributing flyers for the Shūni O-Jizō-san Pilgrimage (Figure 4), using the less formal and religiously inflected term meguri, meaning simply a round of visits to different key locations. The rest of the flyer and the other materials, however, referred to "junrei," identifying it clearly with the schema of traditional Buddhist practice. As Reader (2014) has shown, the range of practices, objects, and entities that might become incorporated into notions of pilgrimage in Japan is broad, and that other non-religious forces have long influenced and shaped what Japanese people think about pilgrimage today. Yet there was a quaint, handmade quality to this pilgrimage - the cut and pasted photocopied flyers were more like the familiar neighborhood bulletins circulated via the kairanban (a clipboard of local announcements passed from one home to the next within a block unit) rather than the glossy adverts for bus tours to Shikoku or Ise.

Along with the flyers came small, breast-pocket-sized booklet that briefly explained the pilgrimage's purpose: “This Jizō Pilgrimage (junrei) is not only for devoted believers, but also to cleanse the environment that children are placed in today and to control harmful crimes against them." This statement was then followed by a list of six guidelines:

1. We ask that you do your best [to go] during the time periods when children are commuting to and from school: 7:30am-8:45am/ 12pm-5pm

2. When on the street, please greet children who pass by

3. Please affix your Shū-chan button to your chest 
4. Please obey traffic rules and take caution to avoid traffic accidents

5. Please complete the pilgrimage by following the rules and stamping [the booklet]

6. The pilgrimage is completed after four circuits

Most pages in the booklet were simply divided into four empty quadrants for affixing adhesive stamps that would be placed by volunteers at each shrine. Each of these blank pages were labeled with the location and number of a different Jizō shrine. The stamps indexed not only the Jizō enshrined at each location, but also the ritual act of offering and care of the pilgrimage, and one by one, these badges of accomplishment drew the pilgrim into a closer identification with Jizō and the benevolent watchfulness he represents.

More than a simple record, these kinds of booklets, called nōkyo, have been a mainstay of other religious pilgrimages in Japan since the medieval period, when they were used as a kind of passport for pilgrims traveling outside of their feudal domain. Later, the nōkyo, bearing the official stamp and other marks from each temple visited, became magical talismans in their own right, or were popularly believed to be "passport to the Pure Land after death" (Reader 2005:22). One older woman told me to keep the booklet clean and safe, adding that she had one from another pilgrimage she did years ago and planned to have it placed in her coffin when she is cremated in order to take them to the other world as proof of meritorious achievements. "Maybe I should take this one too?" she said, half-joking as she looked at the book in her hands.

The booklets also contained a copy of the "Heart Sutra" (prajñāpāramitā), which is commonly recited by visitors to Buddhist sacred sites on other Japanese pilgrimages. More than anything else, this sutra marks the pilgrimage's relation to other religious pilgrimages and the repetitive, ritualized, non-sectarian spirituality that they represent. On the final page 
of the booklet, however, a space was reserved for the recognition of completion to be stamped with the seal of the association president (Kawashima-san). Even in this simple booklet, authorities were being rearranged in ways that placed personal spiritual well-being and community well-being on common ground (quite literally), with the personal connection to the sacred spaces and the social connection to the neighborhood co-constituting each other.

Along with the booklet, I was also given a timetable for recording my participation in the pilgrimage and a map of the neighborhood with the locations of the numbered Jizō Shrines. Having participated in the local Shinto festival the previous month, I immediately recognized the standard district map. It was the same one that we followed when we paraded the local deity (kami) through the neighborhood in a portable shrine. In both cases civic cho organizations were central, and the religious and civic functions blurred as organizers and participants negotiated practical concerns and traditional aesthetics. However, unlike the matsuri, the Shūni O-Jizō-san Pilgrimage map had no marks identifying a route, only numbered locations of shrines. In connecting the numbered shrines in the order they are numbered, the route does not form an exact circuit around the schools. The openness of the route encouraged pilgrims to use their judgment or create their own route as they wandered from area to another, stopping off to collect stamps and then on to secondary sites to shop or socialize, rest and observe, just as one might on other pilgrimages (Figure 4).

Figure 4: Map of the Shūni O-Jizō-san Pilgrimage. Numbered shrine locations are linked in order with straight red lines. Large red dots represent the first and last numbered stations. Yellow blocks are schools.

Surrounding the road map were twenty-five postage stamp sized, slightly obscure black and 
white photos of each shrine and the corresponding block location, like a travel brochure or a Buddhist mandala (12). Numbering followed the order generally taken when writing Japanese characters - left to right, top to bottom — so that the numbers did not indicate a "beginning" or an "end" to the pilgrimage.

A blank passport, a map with no route, an itinerary with no dates or times. As a travel plan, my materials seemed woefully inadequate. Yet, as a pilgrimage, they also presented a field of possibility, an opportunity for watchful agency that required walking out into the world. As I took the map and booklet, I felt ungrounded rather than guided, a feeling that melted as I began to walk from shrine to shrine, one step at a time, eyes scanning the streetlevel structures and greeting neighbors. I was aware that my pace was quicker and my gait longer than most of the older people I met at the gathering in the park; my style of walking and watching was different; my knowledge of place and the way I moved depended not only on the practice but the way it was embodied.

\section{Walking (again)}

After about a week, I soon forgot about the pilgrimage as other parts of my fieldwork began to demand attention and the day of my departure from the field approached. Every now and then as I ran errands or made my way to the train station, I noticed people stopping at the shrines to place a coin in the offering box, and pick up a stamp for their book. Mostly I relied on catching up at the regular Social Welfare Cooperative Association meetings, where everyone traded updates on their progress.

Though few recited the entire Heart Sutra, they all told me that they asked Jizō to watch over the children. Sometimes they walked alone, at other times in pairs. They stopped at shrines while on errands, or walking dogs. In one instance, a woman called me over to look at her cane, which was decorated with two small, brocaded protective talismans, one of 
which had a small bell attached. She explained that she used to make it out to several shrines and temples every year, but now it was too hard. We joked with each other that her cane is like a pilgrim's staff, and she held it up, smiling proudly. Understanding the pilgrim and the objects she uses to reimagine the landscape brings us from the cane to the street, and once again, to walking.

If the practice of watching over others was a means of blending civic duty with the protective benevolence of Jizō-san, walking was a means to becoming visible, not as a traffic hazard, but as a socially conscious pilgrim. Walking was not a requirement of every pilgrimage, but it was often one of the first things that pilgrims recalled when asked about their motivations and experiences on the road, and it was explicitly encouraged by organizers as a means to being watchful.

Walking on a pilgrimage not only creates the moral self, but it creates nature as a meaningful space negotiated through an aesthetic sense of the sights, smells, and feelings that bring possible pasts and possible futures into the field of the present (cf. Saito 2007). At the very least, pilgrims I spoke with based their activity on assessments of the weather, gauging the summer heat and humidity not only through weather reports, but on bodily barometers such as joint pain.

Walking, especially in pilgrimage, "maps" the territory; it integrates a physical terrain with memories and bodily feelings (Barthes 1982,36; de Certeau 1994; Ingold 2004, 329; Ingold 2011, 299; Schattschneider 2003). The thickness and malleability of the borders of the Shūni O-Jizō-san Pilgrimage experience are formed and reformed through the practice of not only "watching," but also "walking"(ayumi), a word that in Japanese, indicates not only taking steps, but also any process of nature's unfolding, such as the phrase "the process of aging" (oi no ayumi). Walking thus occurs not only in a literal sense of physical ambulation, but in the sense of the often purposeful, though sometimes wandering journey through life, 
punctuated by people, places and events that variously provide obstacles, guidance, rest, and chances for reflection and awe. In this sense, walking was a narrative, but it was also a generator of other narratives that could be commended at community meetings and shared in roadside chats with neighbors.

These pilgrims seemed quite different than the city walkers described by de Certeau (1984) whose paths intertwine with the city plan as "unrecognized poems in which each body is an element signed by many others" $(1984,128)$. For de Certeau, the walker is blind to the voyeur's vision, just as the voyeur who takes in the God-like panorama is blind to walkers. I would add that pilgrims add their own vision, their own design and its implied revelation, to their narrative composition of the landscape (Ingold 2011, 199-200). On the Shūni O-Jizō-san Pilgrimage, the walkers are watchers, who visualize the city through an alternative optic of sacred practice, becoming a watchful presence like Jizō-san himself. By creating these new pathways, they create embodied metaphors (Kirmayer 1992) that symbolically align civic activity with other forms of spiritual and moral effort.

For these older adults, the civic and religious aspects of the pilgrimage did not conflict, and all agreed that it would not be any good to have one without the other. The pilgrimage provided a counter-narrative to discourses of dependence and being burdensome in Japan's aging society. In the context of creating a landscape of walking, watching, and worship, it is the aesthetic creation of the "map" more than the territory itself that conveys the sense of civic duty, the cane rather than the staff that signaled a divine presence.

\section{Conclusion}

As a local civic response to community safety initiated and conducted by older adults, the Shūni Jizō-san Pilgrimage was a remarkable expression of elder agency, creativity, and engagement. In this sense, it was a path to well-being, of welfare in the sense of both personal 
"good living" and doing good in the world, of a wholeness that spilled across and seeped through bureaucratic, sectarian, and generational vectors of exclusion (Terasaki 2013). As the pilgrims made their rounds, they were indistinguishable from anyone else until they approached one of the small shrines wedged between buildings or tucked under the eaves of a shop. In a soft chorus they would chant their sutras, and bow their heads, making sure to take a small stamp for their booklet before moving on again down the road wandering off the path to stop at a friend's house, a candy shop, or a cafe to rest and chat. In unrushed steps, the neighborhood was aesthetically redesigned as a place where older people watched over and safeguarded children and each other.

This was no ordinary "neighborhood-watch" program, but was it a pilgrimage? The Shūni pilgrimage was familiar and unadorned, it was inclusive and open to multiple routes and motivations. As an extension of the typical prayers for the family and community, pilgrims who asked Jizō for the protection and care of children reconstituted themselves and their well-being as watchful guardians of their neighborhood. It serves as an illustration of Coleman's $(2002,363)$ contention that pilgrimage is best approached as a means of opening up and connecting other aspects of human behavior and social organization (both the everyday and the particular), including movement, memory, age, and aesthetics.

Because the Jizō shrines stood independently of temples and were already cared for by the community organizations, there was no need to involve Buddhist institutions or clergy, and thus the pilgrimage retained its civic focus despite its incorporation of religious landmarks and symbols. The practice of "watching over," as refracted through the image of Jizō-san, rewrites the idea of the Panopticon by making the bodies and actions of older community members visible as they walk the circuit—visibility was not as "a trap," or form of social exclusion (Foucault 1977, 200-204), but as pilgrimage, it liberated new forms of subjective becoming. Maps, records, and conversation along the wandering route brought 
new forms of visuality and aesthetic apprehension to practices of surveillance, recapturing it for the work of self-creation. Spiritual, moral and aesthetic potential and design dissolved recognizable boundaries between civic and religious meanings, facilitating a more coherent and meaningful experience of self and community.

In contrast to the more well-established, popularly recognized pilgrimage routes, the Shūni O-Jizō-san Pilgrimage did not involve lengthy preparation and investment, nor did it entail enduring great physical hardships or promise great miracles. Walkers did not cast off their canes or crutches at its completion, the way pilgrims once did on the 88 temple Shikoku Pilgrimage. The Shūni O-Jizō-san Pilgrimage revealed more fundamental symbols and structures of pilgrimage stripped from the myths, legends, and the theological baggage.(13) At the same time, the pilgrimage is itself a kind of "resemblance,"' symbolically situated within the tradition of pilgrimage and by this analogical association, able to borrow from the symbolic associations and invite aesthetic creativity. Many of the older adults who completed the Shūni O-Jizō-san Pilgrimage had completed other pilgrimages during their lives, and as result were able to readily draw on the practical sense of feelings that accompanied their recollection. But it would be wrong to think of such resemblance as a reduced or partial imitation of "true" religious pilgrimage, since its design through watching and walking generated memories and meanings that exceeded those bounds.

Though only a rough sketch, my hope is that this description of the Shūni O-Jizō-san Pilgrimage provides an example of how the anthropology of pilgrimage might be expanded to better incorporate Japanese case studies, which tend to be dominated by older adult pilgrims. Anthropologists examining pilgrimage have sometimes noted the presence and even leadership of older people in pilgrimage, but rarely have they explored how issues of visibility, agency, emplacement and mobility that arise within aging welfare states have implications for the meaningful self-formations that arise out of walking and watching. This 
case highlights ways our ethnographic material often requires us to unbound not only ideas of pilgrimage, religion, and ritual,, but also the aesthetics of social welfare, age, generation, and well-being. This unbounded staging ground becomes a means for recreating the familiar, and becoming a watchful presence rather than an invisible ghost. The decentered map and its route-less route offered older adults opportunities as they walked between shrines to reconsider themselves as moral bodies that create the local geography of community, countering social concerns of a dependent, isolating old age without adhering to social programs designed by social welfare and health agencies to promote "active aging." Like the continuous, circuitous, wandering path of the pilgrim, aging well is found in the present attainment of watching and walking with each step.

\section{ENDNOTES}

(1) Japanese orientations toward the ground and its implications for values or dispositions towards feelings of interdependence and attention to others have been explored by cultural psychologists through studies of visual perception, aesthetic preference, and horizon line (Nisbett and Masuda 2012, Masuda et al. 2014, e.g.)

(2) While the English words roughly gloss their Japanese equivalents, the English translations were also meant to provide terms that could enter into a conversation with other work on "walking" and various forms of "watching" and visualizing (Ingold and Vergunst, eds. 2008; Grasseni, ed. 2007). The Japanese terms were used by participants to describe activities alongside the pilgrimage, but were taken out of their specific contexts and abstracted to represent broader themes that arose from the ethnographic data. Mimamori is an interesting kind of watching because it was used to refer to both the older people watching over children, 
and Jizō watching over the community. Ayumi emphasizes the onward trudging steps, but is also used poetically to talk about the procession of a life course (jinsei no ayumi) into old age. (3) The Saikoku or "western" pilgrimage is composed of a circuit of 33 temples whose main temple image is that of the Bodhisattva Kannon (Avalokitesvara) (Sato 1989). It is extremely popular for those living in Kyoto and the surrounding area since most of the locations are close by and easier to travel to by bus or automobile. Even in the city, however, walking remains critical to the pilgrimage and walking through the temple gates and to the main hall itself are kinesthetically tied to bowing or circumambulating.

(4) I translate the word hokora (a small structure for housing a sacred object) here as "shrine," a word typically reserved for structures dedicated to Shinto kami (jinja). "Buddhist shrines" therefore can be distinguished from Buddhist temples (tera, bukkaku), which function as ritual and administrative institutions, or Buddhist altars (butsudan, saidan), which are ritual spaces within a structure such as a temple, a home, or shrine.

(5) The Shūni school district is located in an area on the periphery of Kyoto city that was still dominated by rice fields until a growth of urbanization in the 1960s led to the construction of more businesses and residential zoning. These areas may feel the generational and demographic shift more acutely than other areas as a result of the rapid change in the landscape.

(6) I used the word "pilgrimage" here to indicate both the word junrei and meguri which were used interchangeably by organizers in presentations and on written materials. While general usage of these terms in Japan often crosses sacred/profane boundaries, both indicate a journey, circuit, or tour that has special meaning for the traveler (as opposed to commuter travel or purely functional travel, the process in itself has meaning). (7) Children living in Kyoto, a city of over 1.4 million people, are encouraged to commute to school on foot, often times walking in streets without dedicated pedestrian walkways. Commuting on foot is 
encouraged and monitored throughout Japan, through the use of report books, zoning restrictions on bicycles in school areas, and the hidden power of confidential school reports (naishinsho). In the Shūni school district, most students commute between ten to fifteen minutes on foot each way, but others studying education in Japan have reported that some students may commute on foot for 40-50 minutes each way, often with little monitoring or clear guideposts for their routes (Moorehead 2006, July 6 H-Japan email; Nishino 2006, July 7 H-Japan email listserv communication)

(8) For more on the ways civil society organization and neighborhood festivals or other community events in Japan build neighborhood solidarity (machizukuri) within a generational cohort or sense of local identity see Bestor 1989; Ivy 1995, 103-140; Kawano 2005; Robertson 1991; Sorenson 2009; Traphagan 2000b.

(9) One popular folk tale involves Jizō granting wishes to an old man who makes offerings of hats to Jizō statues on a cold day, but there are several other tales involving miracles in Chozen-Bays 2001 and Glassman 2011.

(10) The most extensively studied Japanese pilgrimage, the 88 temple Shikoku henrō, for example, formally "ends" at Mangan Temple, but many pilgrims do not consider their circuit complete without a visit sectarian head temple of the Shingon sect at Mt. Koya, which is usually the first temple visited before embarking on the pilgrimage. Similarly, Moerman, writing of the Kumano Pilgrimage notes that circuits, though sequential, are doubled (forward and reverse) $(2005,128)$.

(11) In some ways this resembles Dahlberg's (1991) description of the way pilgrimage to Lourdes recontextualizes sick and suffering bodies, identifying them with "visionary" (31) sufferers, and "closer to the sacred than is the 'healthy' devotee" (46)

(12) Mandala are visual representations of enlightenment used in ritual and meditative practice in Japanese Buddhism, and particularly in esoteric traditions, where they feature a 
vast number of buddhas, bodhisattvas, gods, and other celestial beings (see Abé 1999)

(13) Though pilgrimage is by no means a new subject for anthropologists or sociologists, most of the scholarly work on contemporary Japanese pilgrimage has looked only at the most popular and historically significant routes: the 88 temples of Shikoku (Statler 1983; Reader and Swanson 1997; Hoshino 1997; Reader 2005); the Kumano Sankei (a UNESCO World Heritage Site ) (Moerman 2005): the 33 Sites of Kannon Saikoku Pilgrimage (Sato 1989); Inari Taisha (Smyers 1997); Mount Osore (Miyazaki and Williams 2001, Ivy 1995) and Konpira Shrine (Thal 2006)(2).

Word Count: 8986

References

Abé, Ryūichi.1999. The Weaving of Mantra: Kūkai and the Construction of Esoteric Buddhist Discourse. New York: Columbia University Press.

Anderson, Benedict. 1991. Imagined Communities: Reflections on the Origin and Spread of Nationalism, Revised Edition. New York: Verso.

Danely, Jason. 2012a. Repetition and the Symbolic in Contemporary Japanese Ancestor Memorial Ritual. Journal of Ritual Studies, 26(1): 19-32.

--- 2012b “Encounters with Jizō-san in an Aging Japan,” In Studying Buddhism in Practice, edited by John Harding. pp. 118-129. New York: Routledge.

--2014. Aging and Loss: Mourning and Maturity in Contemporary Japan. New Brunswick, NJ: Rutgers University Press.

Badone, Ellen \& Roseman, Sharon.R. eds.2004. Intersecting Journeys: The Anthropology of Pilgrimage and Tourism. Chicago: University of Illinois Press. 
Bajc, Vida, Coleman, Simon, \& John Eade. 2007. Introduction: Mobility and Centring in Pilgrimage. Mobilities, 2(3): 321-329.

Barthes, Roland. 1982. Empire of Signs. Trans. Richard Howard. New York: Hill and Wang. Bauman, Zygmunt. 1996. From Pilgrim to Tourist - or a Short History of Identity. In Questions of Cultural Identity, edited by Stuart Hall \& Paul de Gay. pp. 18-36. London: Sage Publications Ltd.

Bestor, Theodore. 1989. Neighborhood Tokyo. Stanford: Stanford University Press.

Brown, Naomi.2003. Under One Roof: The Evolving Story of Three Generation Housing in Japan. In Demographic Change and the Family in Japans Aging Society, edited by John W. Traphagan \& John C. Knight. pp.53-71. Albany: State University of New York Press. Chozen Bays, Jan. 2001. Jizo Bodhisattva Guardian of Children, Travelers and Other Voyagers. Boston: Shambala.

Coleman, Simon \& Eade, John, eds. 2004. Reframing Pilgrimage: Cultures in Motion. New York: Routledge.

Coleman, Simon \& Elsner, John, eds. 1995. Pilgrimage Past and Present: Sacred Travel and Sacred Space in the World Religions. London: British Museum Press.

Coleman, Simon. 2000. Meanings of movement, place and home at Walsingham. Culture and Religion: An Interdisciplinary Journal, 1(2): 153-169.

---2002. Do you Believe in Pilgrimage?: From Communitas to Contestation and Beyond Anthropological Theory, 2(3):355-68.

Crain, Mary M. 1997. The Remaking of an Andalusian Pilgrimage Tradition: Debates Regarding Visual (Re)presentation and the Meanings of "Locality" in a Global Era. In Culture, Power, Place: Explorations in Critical Anthropology, edited by Akhil Gupta and James Ferguson. pp.291-311. Durham, NC: Duke Univerity Press.

Dahlberg, Andrea. 1991. The Body as a Principle of Holism: Three Pilgrimages to Lourdes. 
In Contesting the Sacred, edited by John Eade and Michael J. Sallnow. pp.30-50. London: Routledge.

De Certeau, Michel. 1984. The Practice of Everyday Life. Trans. Steven Randall. Berkeley: University of California Press.

Dubisch, Jill. 1995. In a Different Place: Pilgrimage, Gender, and Practice at a Greek Island Shrine. Princeton, NJ: Princeton University Press.

Eade, John \& Michael J. Sallnow. 1991. Contesting the Sacred: The Anthropology of Christian Pilgrimage. London: Routledge.

Foucault, Michel. 1977. Discipline and Punish: The birth of the prison. New York: Vintage Books.

Fujiwara, Kuniko. 2012. Rethinking "Successful Aging" from the Perspective of the Jizō with Replaceable Heads. Anthropology \& Aging Quarterly, 33(3): 104-111.

Dubisch, Jill \& Michael Winkelman, eds. 2005. Pilgrimage and Healing. Tucson, AZ: University of Arizona Press.

Genda Yuji. 2007. Jobless Youths and the NEET Problem in Japan. Social Sciences Japan Journal, 10(1): 23-40.

Glassman, Hank. 2011. The Face of Jizō. Honolulu: University of Hawai’i Press.

Goffman, Erving. 1971. Relations in Public: Microstudies of the Public Order. London: Allen Lane.

Grasseni, Cristina, ed. 2009. Skilled Visions: Between Apprenticeship and Standards. New York: Berghahn Books, Inc.

Hoshino, Eiki. 1997. Pilgrimage and Peregrination: Contextualizing the Saikoku Junrei and the Shikoku Henro. Japanese Journal of Religious Studies, 24 (3-4): 271-299. Ingold, Timothy \& Jo Lee Vergunst, eds. 2008. Ways of Walking: Ethnography and Practice on Foot. Burlington, VT: Ashgate. 
Ingold, Tim. 2004. Culture on the Ground The World Perceived Through the Feet. Journal of Material Culture, 9(3): 315-40.

---2005. Up, Across and Along. In PLACE and LOCATION. Studies in Environmental Aesthetics and Semiotics, edited by E. Näripea, V. Sarapik, \& J. Tomberg. pp. 21-36. Tallinn: Estonian Academy of Arts.

---2011. Being Alive: Essays on Movement, Knowledge and Description. London; New York: Routledge.

Ishiguro, Kuniko. 2008. Thinking about Younger People's Employment in $21^{\text {st }}$ Century

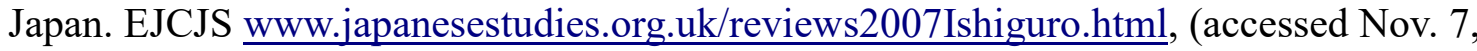
2011)

Ivy, Marylin. 1995. Discourses of the Vanishing: Modernity Phantasm Japan. Chicago: University of Chicago Press.

Kawano, Satsuki. 2005. Ritual Practice in Modern Japan: Ordering Place, People and Action. Honolulu: University of Hawai’i Press.

Kirmayer, Laurence. 1992. The Body as Metaphor. Medical Anthropology Quarterly, 6(4): 323-346.

Kojima Hiroshi. 2000. Japan: Hyper-aging and Its Policy Implications. In Aging East and West: Families, States and the Elderly, edited by Vern L. Bergston, Kyong-Dong Kim, George C. Myers \& Ki-Soo Eun. pp.95-120. New York: Springer.

Kyoto City Bureau of Population Statistics 2014. http://www.city.kyoto.jp/sogo/Population/, accessed September 20, 2014.

La Fleur, William. 1992. Liquid Life: Abortion and Buddhism in Japan. Princeton, NJ: Princeton University Press.

Long, Susan Orpett. 2003. Becoming a Cucumber: Culture, Nature, and the Good Death in Japan and the United States. Journal of Japanese Studies, 29 (1): 33-68. 
Masuda, T., R. Gonzalez, L. Kwan, and R. E. Nisbett. 2008. Culture and Aesthetic

Preference: Comparing the Attention to Context of East Asians and Americans. Personality and Social Psychology Bulletin, 34 (9): 1260-75. doi:10.1177/0146167208320555.

Miyazaki, Fumiko and Williams, Duncan. 2001. The Intersection of the Local and Translocal at a Sacred Site: The case of Osorezan in Tokugawa Japan. The Japanese Journal of Religious Studies, 28(3-4): 399-440.

Moerman, D. Max. 2005. Localizing Paradise: Kumano Pilgrimage and the Religious

Landscape of Premodern Japan. Harvard East Asian Monographs. Cambridge, MA: Harvard University Asia Center.

Morioka, Kiyomi. 2012. "Muen Shakai" ni Kōreiki wo Ikiru [Old Age in the "Connectionless Society”]. Tokyo: Kōsei.

Nisbett, Richard E., and Takahiko Masuda. 2003. Culture and Point of View. Proceedings of the National Academy of Sciences, 100 (19): 11163-70.

Notermans, Catrien. 2007. Loss and Healing: A Marian Pilgrimage in Secular Dutch Society. Ethnology, 46(3): 1-17.

Porcu, Elizabeth. 2012. Observations on the Blurring of the Religious and the Secular in a Japanese Urban Setting. Journal of Religion in Japan 1(1): 83-106.

Rapport, Nigel. 2008. On Well-Being, Being Well and Well-Becoming: On the Move with Hospital Porters. In Culture and Well-Being: Anthropological Approaches to Freedom and Political Ethics, edited by Alberto Corsin Jiménez. pp. 95-112. Ann Arbor, MI: Pluto Press. Reader, Ian. 1995. Social Action and Personal Benefits in Contemporary Japanese Buddhism. Buddhist-Christian Studies, 15: 3-17.

--- 2003 Local Histories, Anthropological Interpretations, and the Study of a Japanese Pilgrimage. Japanese Journal of Religious Studies, 30(1-2): 119-132.

---2005 Making Pilgrimages: Meaning and Practice in Shikoku. Honolulu: University of 
Hawai'i Press.

---2014. Pilgrimage in the Marketplace. London: Routledge.

Reader, Ian \& Paul L. Swanson. 1997. Editor's Introduction: Pilgrimage in the Japanese

Religious Tradition. Japanese Journal of Religious Studies, 24(3-4): 225-270.

Reader, Ian \& George Tanabe. 1998. Practically Religious Worldly Benefits and the

Common Religion of Japan. Honolulu: University of Hawaiì Press

Roberts, Glenda S. 2002. Pinning Hopes on Angels: Reflections from an Aging Japan’s

Urban Landscape. In Family and Social Policy in Japan: Anthropological Approaches, edited by Roger Goodman. pp. 54-91. Cambridge: Cambridge University Press.

Robertson, Jennifer. 1991. Native and Newcomer: Making and Remaking a Japanese City. Berkeley, CA: University of California Press.

Rodríguez del Alisal, Marta, Peter Ackerman \& Dolores P. Martinez, eds.2007. Pilgrimages and Spiritual Quests in Japan. New York: Routledge.

Rowe, Mark Michael. 2011. Bonds of the Dead: Temples, Burial, and the Transformation of Contemporary Japanese Buddhism. Chicago: University of Chicago Press.

Saito, Yuriko. 2007. The Moral Dimension of Japanese Aesthetics. The Journal of Aesthetics and Art Criticism. Special Issue: Global Theories of the Arts and Aesthetics, 65(1): 85-97. Sangren, Steven P. 1993. Power and Transcendence in the Ma Tsu Pilgrimages of Taiwan. American Ethnologist, 20 (3): 564-82.

Sato Hisamitsu.1989. Gendai no Junrei: Saikoku Junrei ni Tsuite [Contemporary Pilgrimage: On the Saikoku Pilgrimage]. In Kazoku Shakaigaku Noto, edited by Maeda Takashi. pp. 183222. Kyoto: Kansai Daigaku.

Schattschneider, Ellen. 2003. Immortal Wishes: Labor and Transcendence on a Japanese Sacred Mountain. Durham, NC: Duke University Press.

Smelser, Neil J. 2009. The Odyssey Experience: Physical, Social, Psychological and Spiritual 
Journeys. Berkeley: University of California Press.

Smyers, Karen A. 1997. Inari Pilgrimage: Following One's Path on the Mountain. Japanese Journal of Religious Studies, 24 (3-4): 427-452.

Sorenson, André. 2009. Neighborhood Streets as Meaningful Spaces: Claiming Rights to Shared Spaces in Tokyo. City and Society 21(2): 207-229

Statler, Oliver. 1983. Japanese Pilgrimage. New York: Morrow.

Suzuki, Nanami. 2013. Preface. In Anthropology of Aging and Well-Being: Searching for the Space and Time for Cultivating a Life Together, Senri Ethnological Studies Vol. 80, edited by Nanami Suzuki. pp. i-ix. Osaka, Japan: National Museum of Ethnology.

Takagi, Emiko \& Merril Silverstein. 2006. Intergenerational Coresidence of the Japanese Elderly: Are Cultural Norms Proactive or Reactive? Research on Aging, 28(4): 473-492. Takenaka, Hoshirō. 2000. Kōreisha no Kodoku to Yutakasa [The Solitude and Richness of the Elderly]. Tokyo: Nihon Hōsō Shuppan Kyōkai.

Terasaki, Hiroaki. 2013. Reconsidering the Meaning of Nourishing Life: An Attempt to Energize the Concept of Well-Being. In Anthropology of Aging and Well-Being: Searching for the Space and Time for Cultivating a Life Together, Senri Ethnological Studies Vol. 80, edited by Nanami Suzuki. pp. 21-32. Osaka, Japan: National Museum of Ethnology. Thal, Sarah. 2005. Rearranging the Landscape of the Gods: The Politics of a Pilgrimage Site in Japan. Pp.1573-1912. Chicago: University of Chicago Press.

Traphagan, John W. 2000a. Taming Oblivion: Aging Bodies and the Fear of Senility in Japan. New York: SUNY Press.

---2000b. Reproducing Elder Male Power through Ritual Performance in Japan. Journal of Cross-Cultural Gerontology, 15(2): 18-97.

--2006. How to be a Good Rōjin: Senility, Power and Self-Actualization in Japan. In Thinking about Dementia: Culture, Loss, and the Anthropology of Senility. Annette Leibing 
and Lawrence Cohen eds. New Jersey: Rutgers University Press.

Turner, Edith and Turner, Victor. 1978. Image and Pilgrimage in Christian Culture. Oxford: Blackwell.

Yabe Takeshi. 2012. Hitori de Shindemo Kodoku ja nai: "Jiritsushi” Senshinkoku America [Dying Alone, but not Lonely: America "Independent" the Developed Country]. Tokyo: Shinchō Shinsho.

Zielenziger, Michael.2007. Shutting Out the Sun: How Japan Created its own Lost Generation. New York: Random House, Inc. 